\title{
HUMAN FACTOR IN INDUSTRY 4.0 IN POINT OF VIEW ERGONOMICS IN SLOVAK REPUBLIC
}

\author{
Petra Marková, Vanessa Prajová, Mária Homokyová, Martina Horváthová
}
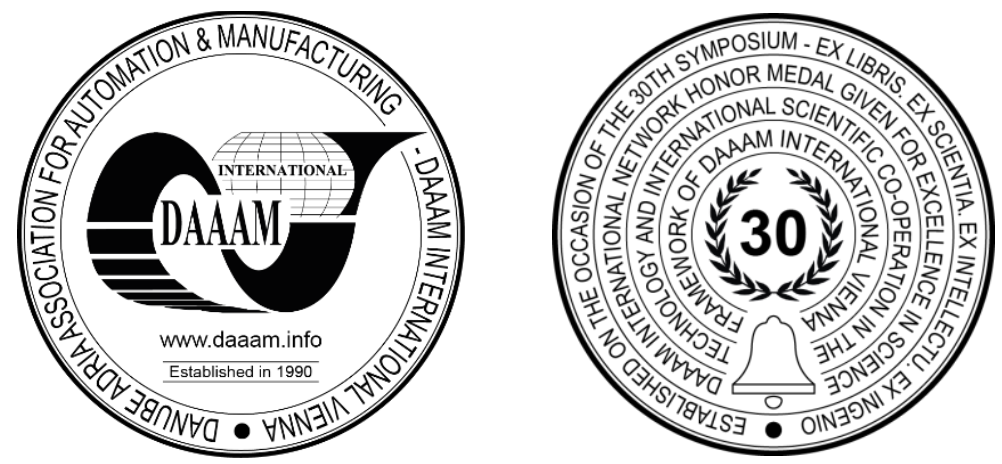

This Publication has to be referred as: Markova, P[etra]; Prajova, V[anessa]; Homokyova, M[aria] \& Horvathova, M[artina] (2019). Human Factor in Industry 4.0 in Point of View Ergonomics in Slovak Republic, Proceedings of the 30th DAAAM International Symposium, pp.0284-0289, B. Katalinic (Ed.), Published by DAAAM International, ISBN 978-3-902734-22-8, ISSN 1726-9679, Vienna, Austria

DOI: $10.2507 / 30$ th.daaam.proceedings.037

\begin{abstract}
At present, the digitization of the company and company's processes is a prerequisite for the success and competitiveness of companies in various industries. The answer to this need is the Industry 4.0 concept. There is an idea that companies will have sequentially interconnected machines, equipment, warehouses, and production lines, using a common cyberphysical system integrating computational physical processes and sensor-driven feedback and control processes, with physical processes that complement computer processes. With this focus, a number of projects have been developed on human-machine interactions in 3D industrial applications [11]. All these changes in the production environment will also have an impact on the change in the status of the human workforce in the labour process. When moving to automated production, there will be a tendency to involve humans in the production process less and less physically, which will have a significant impact on changes in the effects of risk factors on work and the work environment on humans. This paper provides an insight into how changes in the production environment will affect the workforce. It suggests which risk factors need to be solved when implementing the Industry 4.0 into the company's practice.
\end{abstract}

Keywords: human; industry 4.0; work; risk factors; ergonomics;

\section{Introduction}

Today's global and turbulent environment is characterized by rapidly changing conditions. Businesses are thinking deeply about how to innovate their production processes, looking for more efficiency and quality, but they often lack specific projects and strategies to put these requirements into practice [2].

Within the resource-based perspective, information and knowledge have become increasingly recognized as competitive differentiators. In the knowledge-based view, organizational knowledge - such as operational routines, skills or know-how - is acknowledged as the most valuable asset. Currently, an industrial society is transformed into an information society [14].

The Fourth Industrial Revolution ("Industry 4.0"), which is currently underway and focuses on the implementation of the internet of things and internet of services the production environment [8]. The drivers of the viability of the Fourth Industrial Revolution are continuous changes, intermittent innovation; virtualization; shrinking product life cycles, globalization, increasing the use of sensors and embedded softwareThe industrial segment is moving towards digital production. The possibilities of using 3D printers, which have the potential for mass application in industrial production, are being addressed [11]. 
Stepping into 4th Industrial revolution has pushed companies to embrace new technologies in order to successfully fulfill customer's demands for high quality and value-added products. In manufacturing, using new technologies results in time saving, smart components, smart products, real time following of the product, transparency, the availability of information, new software possibilities, higher data security [12].

Step between creating a new technology and implementing it in companies are people who have to adapt to the technology and prepare the processes for it before the implementation. The human factor is highly important and it presents a certain risk [12].

The first industrial revolution was the utilization of machines, the second involved assembly lines and mass production, the third employing automation, and now the fourth industrial revolution: cyber physical systems (machines communicating with one another), as shown in Fig. 1. [12].

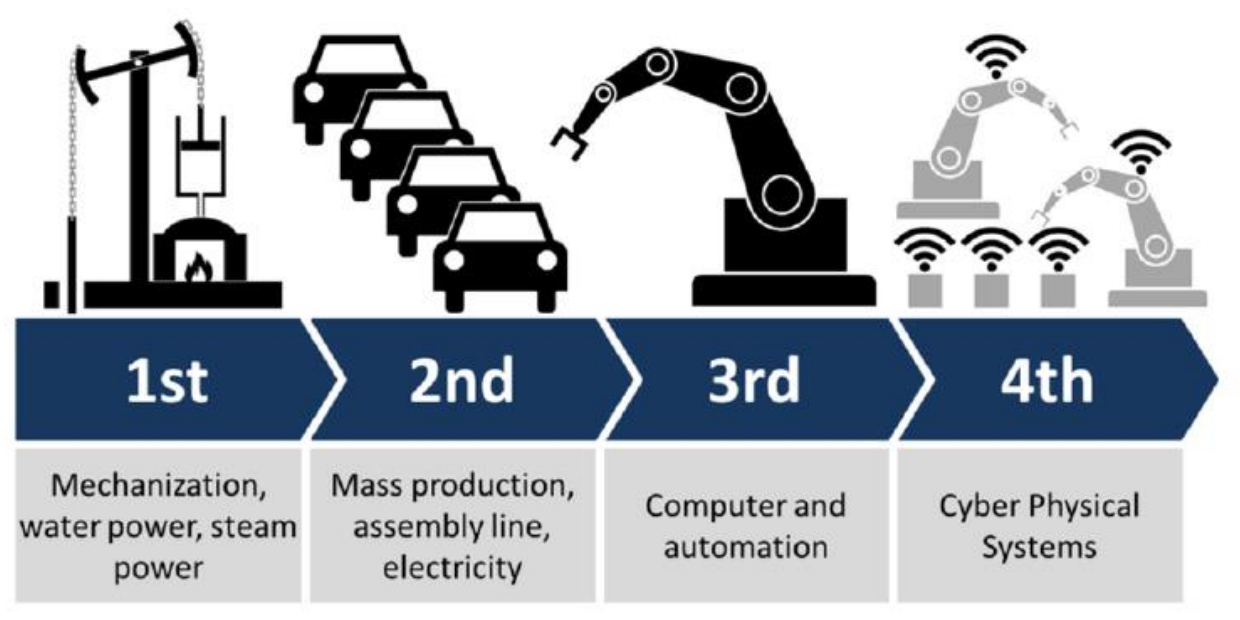

Fig. 1. The Fourth Industrial Revolutions (by Christoph Roser at AllAboutLean.com) [16]

The collaboration between industrial robots and humans is a widely-discussed topic nowadays. Many research papers have been published in this field, but there are still a few uncovered areas, mostly relating to the devices ranging between collaborative robots and small simple industrial robots. There is also lack of optimized safety systems, which could fulfill all safety requirements and manufacturing needs [10].

Nowadays, the beginnings of the 4th Industrial Revolution in companies in the Slovak Republic are reflected in the process of slimming down, where the number of jobs and operations decreases in individual positions [6].

The reverse process takes place in the development of automatic technology, where the effort is to make the machine as efficient as possible to handle as many tasks as possible. This creates the conditions for the automation process in plant operations. The automation process in Slovakia is fastest continuing in companies and plants with foreign owners having company headquarters abroad [6].

In manufacturing, by Industry 4.0 concept, using new technologies results in time-saving, smart components, smart products, real-time following the product, transparency, the availability of information, new software possibilities, higher data security... [12]. In addition to these undeniably positive impacts, it is also necessary to think. Does this change in the production process affect the human involved, if it is positive or not?

\section{Material and methods}

When elaborating the article we rely on material that was collected in companies in Slovakia assoc. Prof. Hatiar and the team of experts around him. The material for assessing the impact of industrial revolutions on employees in Slovakia is quite extensive, as a team of experts around assoc. Prof. Hatiar since 1973. Since the late 1980s, a special "Nordic Questionnaire" questionnaire has been used to collect data for monitoring and assessing the impact of work and working conditions on employees in companies, which has been gradually modified for its use in Slovakia [5], [9]. A significant part of the documents was obtained as part of the work of the Probenefit occupational health service [6]. Further research material was obtained through diploma and doctoral theses of students of the Faculty of Material Science and Technology in Trnava study program "Industrial Management". The obtained data were processed using epidemiological methods in the retrospective cohort and cohort studies of incidence and intensity of difficulties and diseases of the musculoskeletal system, which are indicators of occupational shortages and working conditions in terms of Ergonomics [6].

The next step in gaining the knowledge needed to prevent deficiencies of the work environment in terms of Ergonomics is confronting the results of the epidemiological analysis with the knowledge gained from physically observing the workplaces under evaluation, interviewing employees and evaluating the videos of work cycles made under specific operating conditions. An important source for the assessment is also published results of research by foreign authors. 


\section{Results}

Based on observations in companies in Slovakia, it was found that the implementation of Industry 4.0 took several steps, which proved negative and counterproductive in terms of impact on employees. Entrepreneurs, economists and politicians are based on the belief that full automation will free people from physically and mentally demanding, laborious and harmful work [3].

Observations and studies of the impact of Industry 4.0 on the labor-organizational area in Slovakia in the form of work-related difficulties and illnesses and indicating workplaces shortages in terms of ergonomics and on the prevention of these work-related illnesses and illnesses per employee [6]:

- Return of synchronous assembly and production systems from the 1920s twenty century, where stopping work at one workstation causes the entire assembly or production line to be stopped (introduction of a universal "monitor" operator);

- Changing the demands on the structure of employees due to the development and implementation of universal automatic technology (reduction of workplaces with manual manipulation and execution of work operations by less qualified employees);

- Lean production and increase in the division of work causes a reduction in the content and scope of work (the employee carries out 2 - 3 simple work tasks);

- Increasing division of work, repetition of a small number of simple jobs at a fast pace (frustration of employees);

- Increase in the incidence of difficulties and illnesses indicating workplace shortages in terms of ergonomics in companies in the Slovak Republic;

- Decrease in the physical fitness of younger employees, which makes it impossible to assess the increase in incidences difficulties of the musculoskeletal system with increasing age and occupational exposure;

- Persistence of high incidence of musculoskeletal difficulties (approx. over 70\% of examined persons), which are symptoms of work-related pain syndromes and also indicators of workplace shortages in terms of ergonomics;

- Observations have shown to be the main cause of the emerging difficulties: repetition of a low number of work tasks at a high pace due to excessive division of labour in lean operations, and not rarely in forced working positions. These results must also be taken into account during the launch of Industry 4.0 in the Slovak Republic. This is a presentation of the impact of basic work-related biomechanical factors such as strength, frequency of movements and suitability of working position in terms of ergonomics, referred to as the ergonomic triangle and used in ergonomic risk assessment in ergonomic studies [6].

Table 1 shows the development of localization of intensive musculoskeletal difficulties in total of 4419 employees in industrial companies in the Slovak Republic in the last years, which were processed in the health service Probenefit, both overall and also depending on the prevailing working position sitting and standing. Based on this research it was found that in a ratio of about 3:1 the work activities performed by the posture prevail in standing in comparison with the occurrence of the work performed by sitting down [6].

\begin{tabular}{|c|c|c|c|c|c|c|c|c|c|}
\hline \multirow{3}{*}{$\begin{array}{c}\text { Localization of } \\
\text { musculoskeletal } \\
\text { disorders } \\
\text { difficulties }\end{array}$} & \multicolumn{8}{|c|}{ Working postures } & \multirow{3}{*}{$\begin{array}{c}\text { Significance } \\
\text { of } \\
\text { differences }\end{array}$} \\
\hline & \multicolumn{2}{|c|}{$\begin{array}{c}\text { Overall } \\
(n=4419)\end{array}$} & \multicolumn{3}{|c|}{$\begin{array}{c}\text { Work in sitting } \\
(\mathrm{n}=1213)\end{array}$} & \multicolumn{3}{|c|}{$\begin{array}{l}\text { Work in standing } \\
\quad(\mathrm{n}=3206)\end{array}$} & \\
\hline & Freq. & $\%$ & Freq. & $\%$ & $95 \%$ conf. limit & Freq. & $\%$ & $95 \%$ conf. limit & \\
\hline Neck & 2499 & 56,6 & 918 & 75,7 & $73,29-78,11$ & 1581 & 49,3 & $47,57-51,03$ & $* * *$ \\
\hline Shoulders & 1556 & 35,2 & 463 & 38,2 & $35,79-40,61$ & 1093 & 34,1 & $32,46-35,74$ & $* * *$ \\
\hline Back & 2067 & 46,8 & 682 & 56,2 & $53,79-58,61$ & 1385 & 43,2 & $41,56-44,84$ & $* * *$ \\
\hline Elbows & 781 & 17,7 & 146 & 12,0 & $10,18-3,82$ & 635 & 19,8 & $18,42-21,18$ & $* * *$ \\
\hline Crosses & 2734 & 61,9 & 410 & 33,8 & $31,14-36,46$ & 2324 & 72,5 & $70,95-74,05$ & $* * *$ \\
\hline Palm / Hands & 2718 & 61,5 & 657 & 54,2 & $51,40-57,00$ & 2061 & 64,3 & $62,64-65,96$ & $* * *$ \\
\hline Hips / Thighs & 680 & 15,4 & 109 & 9,0 & $7,39-10,61$ & 571 & 17,8 & $16,49-19,11$ & $* * *$ \\
\hline Knees & 1568 & 35,5 & 167 & 13,8 & $11,86-15,74$ & 1401 & 43,7 & $40,67-46,73$ & $* * *$ \\
\hline Ankles / Feet & 1697 & 38,4 & 280 & 23,1 & $20,73-25,47$ & 1417 & 44,2 & $41,17-47,23$ & $* * *$ \\
\hline
\end{tabular}

Table 1. Comparison of occurrence of localization and intensity of musculoskeletal difficulties in sitting and standing work [6]

When presenting the results of the research carried out in Slovak industrial companies, it is possible, according to the severity, to classify the overall intense musculoskeletal difficulties projected into the body parts as follows: the greatest incidence of difficulties is in the area of crosses, palms and hands, the area of the neck, back, ankles and feet, followed by the area of the knees and shoulders.

If we look at the results of the research in terms of the prevailing working position, there are statistically significant musculoskeletal difficulties in body parts when seated compared to standing work: 
- Neck - the difficulties projected into this body part are related to unsatisfactory conditions of vision at work, suggesting that the work and the rotation of the head will result in the performance of work;

- Shoulders and upper back - these difficulties indicate a high elbow hold while performing work, ie the operator's handling plane is too high and does not match the range and weight of the objects to be handled.

When assessing the research results in Table 1 for standing work, it is possible to determine the order of intensive musculoskeletal difficulties projected into body parts as follows:

- Crosses - these difficulties indicate the occurrence of rotations and deep forward hulls, as well as long reaches in forced working positions and the high pace of work;

- Palms and hands - indicate handling too small or, on the contrary, larger and heavier objects at a high pace and often in forced working positions;

- Knees and ankles - as it is a standing job, there is an overload due to the lack of relaxation on sitting;

- Elbows, loins and thighs - although has musculoskeletal difficulties in standing posture, but is statistically significant compared to sitting posture.

It should be noted that the incidence of work-related musculoskeletal difficulties and illnesses is also gradually showing a negative impact on the psyche [1]. This constitutes a complication in the secondary and tertiary prevention of the above-mentioned health and mental impacts on the employee.

It should be noted that in addition to manual work, there is also work with imaging units, and its negative impact should be reported, especially in the context of Industry 4.0, where this type of work will occur to an increased extent.

Already at work, an increasingly long time sitting at the computer is required, and it is recommended that one should not work with the computer for more than 4 hours a day. The problem is that the materials have to be studied over the Internet, the data is also processed over the Internet and communication is mostly onlineOn the one hand, this represents enormous cost savings as well as a positive impact on the environment, but on the other hand, it has a negative impact on human. They are beginning to manifest civilization diseases themselves in employees, the physical fitness of the younger generation of employees entering the work process is getting lower. Everyday use of the Internet generally leads to the inability to communicate directly.

At the company level, mostly virtual methods are preferred and applied, which do not allow an assessment of the real impact of work and working conditions on employees, thus neither creating opportunities for justified prevention of the occurrence of health problems and work-related difficulties [7].

In Slovakia, work-related problems and disorders of the musculoskeletal system, together with respiratory diseases, are among the most common causes of doctor visits and incapacity for work [6].

In companies within Industry 4.0 in Slovakia, we can observe a new trend in the field of innovation, which affects the occurrence of health problems and makes their prevention more difficult. The flow of new information and changes in market conditions forces them to reassess implemented solutions and apply a continuous flow of innovation that, on the one hand, allows them to adapt dynamically to changes in supply and demand in the global market. But at the same time, the possibility of assessing the impact of individual unfinished innovations on the health of employees, on the other hand, makes it difficult [7]. Companies are trying to solve ergonomic problems within the rationalization of work in a purely virtual way, but this is not sufficient to determine the real impacts of the proposed measures.

\section{Discusion}

Industry 4.0 suggests that it will be possible to automate production in the future so that one no longer participates in the production process. Ergonomic activities are part of the evolutionary processes in both animals and humans that have reached a certain level of central nervous system development and will continue to exist [4]. Therefore, it is not possible to stop paying attention to ergonomic activities in the future.

The positive impact of the application of Industry 4.0 is that through automation it will be possible to completely eliminate the laborious, hazardous and harmful work from the work process. Artificial intelligence is expected to give man additional possibilities that evolution has not provided. On the other hand, however, the mistrust of experts raises the prospect of developing artificial intelligence through computing and the Internet [15].

There is also mistrust in the expansion of Internet services through the Microsoft operating system - Windows 10, which promotes the use of cloud storage and information sharing without ensuring sufficient privacy for users. There is also a failure of social networks that cannot prevent the misuse of users' personal data, their privacy, but also criminal activities [6].

On the other hand, there is a concern that the application of Industry 4.0 may create a problem with rising unemployment since if a person's position in the work process takes over machines completely, a large group of people will have to work elsewhere. It may also affect the purchasing power of the population and the increased demands on the retraining of such employees. However, this is a question of the future but needs to be addressed from the international to the local political level. 
Considering the gradual introduction of Industry 4.0 into practice in Slovak companies, the basic strategy used is to streamline production, which helps to use automatic technology, increases the universality of production, creates conditions for expanding the possibility of use and also affects the decrease in the cost of their operation. However, lean production has according to research results and observations, clearly had a negative impact on the deterioration of work conditions. Lean production is characterized by a reduction in the content and scope of work, ie a person performs only a small number of work tasks with high repeatability. This causes a monotony of work at a high pace of work, which can affect the quality of work performed and also the incidence of difficulties for such an employee. The solution could be, considering whether the process can not be technically solved in conditions more suitable for humans, such as eg. multiple workplaces with multiple operations combined with automated testing.

It often happens, that the dimensions and design of workplaces are not in accordance with the physical dimensions of the employees of the adult population in Slovakia. This is due to the fact that many companies with foreign owners bring the technology from the company headquarter and therefore its solution may be designed for a population with different physical measurements.

There are a number of factors that are at risk for musculoskeletal disorders and diseases, the negative impact of which is already proven by long-term epidemiological studies [1], [13].

From the results of ergonomic analyzes in companies in Slovakia it is possible to state that in the area of work organization are not currently used the most gentle procedures for the implementation of new automated and automatic technology to save employee health. In Western Europe, labour standards are lower than those in Eastern Europe subsidiaries for the same work. For this reason, it can be assumed that the Industry 4.0 process could be implemented using modern technology more friendly to employees.

\section{Conclusion}

The aim of this research was to highlight the importance of the human factor in the implementation of Industry 4.0 in various processes and organizations by considering all possible problems due to the adoption of modern technologies. The aim was to point out that changes in the production process have an impact on the human involved. As research in Slovak companies shows, these changes in terms of ergonomics are not currently showing as positive. It is necessary to work with these findings and to take into account the actual impact of work on people when implementing Industry 4.0 in practice.

A certain limitation of the research is its time consuming obtaining credible outputs. Since at least 1 year is required to monitor the impact of the changes introduced in humans. However, innovation can take turns at a high pace, making it difficult to assess the impact of a rapidly changing work environment on humans. This can be avoided by putting the preventive ergonomic program into practice, where the design of new technologies will already take into account their impact on people in the work process, thus preventing the occurrence of work-related difficulties for workers prior to their occurrence.

The introduction of the Industry 4.0 concept brings benefits for humans in the form of the elimination of heavy, dangerous or harmful work by artificial intelligence. On the other hand, with its gradual introduction into practice, it has a negative impact on humans, as it is realized through slimming in practice, but this means fewer workloads for man, as automatic technology takes on more and more human activities. For the exposed employee, this brings an increase in the monotony of work with all the impacts on physical and mental health.

As could be seen from the results of the research carried out in the conditions of Slovak companies, the incidence of musculoskeletal disorders difficulties in employees is influenced by shortcomings in the spatial solution of workplaces, as the physical dimensions of the Slovak population are not taken into account. Companies also tend to use macroergonomic virtual methods to address ergonomic deficiencies at the company level. These methods are based on estimates and do not take into account the actual impact of work on humans.

The main idea of Industry 4.0 is the pursuit of maximum efficiency, where in the future human work will be replaced by automatic production. The advancement of technology is moving at a high pace and the rapid alternation of innovation in the short term complicates the epidemiological analysis of the causes of employee health difficulties. This problem can be solved through the implementation of an ergonomic program into company practice.

The second step of future research will focus on identifying in detail all factors and barriers affecting humans in implementing the Industry 4.0 concept, from an ergonomics perspective, which can be eliminated by introducing a preventive ergonomic program, creating scope for Industry 4.0 to be put into practice with respect to human labor.

\section{Acknowledgments}

This paper is a part of submitted VEGA project No. 1/0348/17, ,The impact of the coexistence of different generations of employees on the sustainable performance of organisations ".

This paper has been written thanks to support of the Operational Program Research and Innovation for the project: "Research of advanced methods on intelligent information processing", ITMS code: NFP313010T570 co-financed by the European Regional Development Found. 


\section{References}

[1] Barr, A. E.; Barbe, M., F.: (2002). Pathophysiological Tissue Changes Associated With Repetitive Movement: A Review of the Evidence. Physical Therapy, Vol. 82, Issue 2, 1 February 2002, P. 173-187, Available from: https://doi.org/10.1093/ptj/82.2.173, Accessed on: 2019-10-10

[2] Czifra, G.; Szabó, P.; Míkva, M.; Vaňová, J. (2019). Lean Principles Application in the Automotive Industry. In Acta Polytechnica Hungarica, Vol. 16, Iss. 5, 2019, p. 43-62. ISSN 1785-8860 (2018: 1.286 -IF, 3 - JCR Best Q, 0.215 - SJR, Q2 - SJR Best Q). WOS: 000482820300003

[3] Dhanani, S. (2015). Realizing Industry 4.0: Essential System Considerations, Maxim Integrated, Available from: https://www.maximintegrated.com/en/app-notes/index.mvp/id/5991 Accessed on: 2017-10-07

[4] Hatiar, K. (2019). Assessment of the burden of the supporting movement system of employees in companies in Slovak Republic at present, In: Jurkovičová, J,. Štefániková, Z., Proceedings of LIVING CONDITIONS AND HEALTH 2019, s. 269-280, ISBN 978-80-233-4742-6, in press.

[5] Hatiar, K. et all. (2004). Ergonomics and Preventive ergonomic programs (4): Ergonomic analysis using a modified “NORDIC QUESTIONNAIRE” questionnaire. Bezpečná práca. No. 35, Iss. 4, p. 20 - 28, INDEX 49032 ISSN 0322-8347.

[6] Hatiar, K., Bršiak, V. (2018). Industrial revolution and prevention of work-related difficulties and disorders of the musculoskeletal system, In: Jurkovičová, J,. Štefániková, Z., Proceedings of LIVING CONDITIONS AND HEALTH 2017, Public Health Authority of the Slovak Republic, Slovak Society of Hygienists SLS, Institute of Hygiene, Faculty of Medicine, Comenius University, Bratislava, Bratislava, 2018, 17, p. 195 - 211, ISBN 978-80223-4523-1,

Available

from: https://www.fmed.uniba.sk/fileadmin/lf/sucasti/Teoreticke_ustavy/Ustav_hygieny/Webpic/Zborniky/ZPaZ_2018.p df, Accessed on: 2019-10-08

[7] Hatiar, K., Kyselica, O., Baran, D. (2017). Preventive ergonomic program in the company, In: Jurkovičová, J, Štefániková, Z. In: LIVING CONDITIONS AND HEALTH 2017, Proceedings 2017, Public Health Authority of the Slovak Republic, Slovak Society of Hygienists SLS, Institute of Hygiene, Faculty of Medicine, Comenius University, Bratislava, Bratislava, 2017, p. 325-339, ISBN 978-80-7159-229-7, Available from: https://zona.fmed.uniba.sk/fileadmin/lf/sucasti/Teoreticke_ustavy/Ustav_hygieny/Webpic/Zborniky/ZPaZ_2017_u pr.pdf, Accessed on: 2019-10-10

[8] Herčko, J.; Štefánik, A. (2015). Components and principles of the Industry 4.0 concept, ProIn (Productivity and Innovation), Žilina, CEIT, 2015, 16, 2015, 2, p. 47 - 52, ISSN 1339-2271.

[9] Kuorinka, B., et al. (1987). Standardized Nordic Questionnaires for the Analysis of Musculoskeletal Symptoms. Applied Ergonomics, Vol. 18, Iss. 3, September 1987, p.233-237,

[10] Kuts, V.; Sarkans, M.; Otto, T. \& Tahemaa, T. (2017). Collaborative Work Between Human And Industrial Robot In Manufacturing By Advanced Safety Monitoring System, Proceedings of the 28th DAAAM International Symposium, pp.0996-1001, B. Katalinic (Ed.), Published by DAAAM International, ISBN 978-3-902734-11-2, ISSN 1726-9679, Vienna, Austria DOI: 10.2507/28th.daaam.proceedings.138

[11] Mathas, C. (2013). Industry 4.0 is closer than you think, EDN NETWORK, December 02, 2013, Available from: https://www.edn.com/5G/4425363/Industry-4-0-is-closer-than-you-think, Accessed on: 2019-10-15

[12] Mikulic, I. \& Stefanic, A. (2018). The Adoption of Modern Technology Specific to Industry 4.0 by Human Factor, Proceedings of the 29th DAAAM International Symposium, pp.0941-0946, B. Katalinic (Ed.), Published by DAAAM International, ISBN 978-3-902734-20-4, ISSN 1726-9679, Vienna, Austria DOI: 10.2507/29th.daaam.proceedings. 135

[13] NIOSH, (1997). Muskuloskeletal Disorders and Workplace Factors: a Critical Review of Epidemiologic Evidence for Work - Related Muskuloskeletal Disorders of the Neck, Upper Extremity and Low back. Bernard B. (ed.). Cincinnati, DHHS (NIOSH) Publication No. 97 - 141, 1997, 579 p., 1-800-34-NIOSH.1-800-356-4674. Available from, http://www.cdc.gov/niosh/docs/97-141/, Accessed on: 2019-10-10

[14] Paulova, I.; Vanova, J.; Rusko, M.; Hekelova, E. \& Kralikova, R. (2017). Knowledge Managements for Improvement the Competitiveness of Organization, Proceedings of the 28th DAAAM International Symposium, pp.1221-1226, B. Katalinic (Ed.), Published by DAAAM International, ISBN 978-3-902734-11-2, ISSN 1726-9679, Vienna, Austria DOI: 10.2507/28th.daaam.proceedings. 170

[15] Sulleyman, A. (2017). Arteficial Inteligency is Highly Likely to Destroy Humans, Elon Musk Warns. Available from:https://www.independent.co.uk/life-style/gadgets-and-tech/news/elon-musk-artificial-intelligence-openaineuralink-ai-warning-a8074821.html, Accessed on: 2019-10-10

[16] Roser, C. (2015). A critical look on Industry 4.0, Available from: https://www.allaboutlean.com/industry-4-0/, Accessed on: 2019-05-03 